\title{
ANALISIS SISTEM ANTRIAN PELANGGAN SPBU DENGAN PENDEKATAN SIMULASI ARENA
}

\author{
Fuad Dwi Hanggara*, Rama Dani Eka Putra \\ Program Studi Teknik Industri, Fakultas Teknik, Universitas Universal \\ Email: samfu.31@gmail.com; ramadaniekaputra1727@gmail.com
}

Artikel masuk : 08-09-2020

Artikel direvisi : 31-10-2020

Artikel diterima : 01-12-2020

*Penulis Korespondensi

\begin{abstract}
Abstrak -- Kepuasan pelanggan sangat dipengaruhi oleh kualitas layanan yang disediakan oleh perusahaan. Jumlah permintaan yang melebihi kemampuan kapasitas yang ada dapat menyebabkan terbentuknya antrian. Sehingga dilakukan pengamatan pada SPBU 14.294 .739 yang berlokasi di Jl. Raja H. Fisabilillah, Kota Batam, yang memfokuskan pengamatan pada kendaraan roda dua dan pengisian bahan bakar jenis premium dan pertalite dengan durasi pengamatan adalah 2 jam selama 1 minggu. Jumlah antrian, waktu antrian, dan nilai utilitas adalah ukuran performa yang dinilai. Data pengamatan yang telah diperoleh, kemudian diolah dengan software arena, dimana hasil yang didapatkan adalah tidak terjadinya antrian pada sistem namun nilai utilitas yang dimiliki server ialah bernilai satu, yang artinya terlalu sibuk bekerja. Perancangan usulan model perbaikan diperlukan dalam rangka mengefisiensikan utilitas SPBU, yaitu dengan menambahkan jumlah server pada masingmasing jalur pengisian bahan bakar serta penambahan jumlah operator pada masing-masing server, sehingga nilai utilitas mengalami penurunan yang cukup signifikan dimana bernilai dibawah angka satu. Hal ini dapat mempengaruhi tingkat kepuasaan pelayanan konsumen ketika terdapat langkah perbaikan pada bagian server dan operator untuk menanggulangi antrian yang terjadi.
\end{abstract}

Kata kunci: Antrian; Utilitas; Arena; Simulasi

\begin{abstract}
Customer satisfaction is greatly influenced by the quality of service provided by the company. The number of requests that exceed the capacity of the existing capacity can cause queues to form. So those observations were made at SPBU 14,294,739 located on Jl. Raja H. Fisabilillah, Batam City, focuses on observations on two-wheeled vehicles and refueling of premium and pertalite types with an observation duration of 2 hours for one week. Queue count, queue time, and utility value are assessed performance measures. The observation data that have been obtained are then processed with the arena software, where the result is that there is no queue on the system, but the utility value of the server is worth one, which means that it is too busy to work. The proposed improvement model's design is needed to streamline SPBU utility by increasing the number of servers on each refueling line and increasing the number of operators on each server. The utility value has decreased quite significantly, where the value is below number one. This can affect customer service satisfaction when there are corrective steps on the servers and operators to cope with the queues.
\end{abstract}

Keywords: Queue; Utility; Arena; Simulation

\section{PENDAHULUAN}

Suksesnya suatu perusahaan dalam persaingan industri global dapat dilihat melalui berbagai faktor, salah satunya yaitu melalui tingkat kepuasan konsumen yang dimana harus didukung dengan kemampuan perusahaan dalam menyediakan dan menyampaikan produk atau jasa yang dibutuhkan oleh pelanggan (Dewi, 2016). Adanya kepuasan konsumen tentu dapat memberikan beberapa pengaruh positif pada perusahaan, seperti misalnya yaitu peningkatan pendapatan perusahaan serta peningkatan popularitas atau nama perusahaan.

Untuk dapat memperoleh tingkat kepuasan yang optimal dari pelanggan, maka terdapat beberapa hal yang perlu diperhatikan, seperti kualitas dari produk ataupun jasa yang ditawarkan, hingga berbagai penyediaan layanan 
konsumen yang dapat menunjang pemenuhan kepuasan konsumen. Maka dari itu, kualitas pelayanan menjadi kunci keberhasilan dalam mendapatkan penilaian yang baik dari konsumen. Namun, tingginya permintaan yang tidak dibarengi dengan peningkatan jumlah penyedia layanan dapat menyebabkan terjadinya garis tunggu atau antrian yang dapat berpengaruh pada tingkat kepuasan konsumen (Wihdaniah et al., 2018).

Antrian merupakan situasi menunggu untuk menerima pelayanan dari fasilitas yang terbatas (Manalu \& Palandeng, 2019). Antrian terjadi karena kebutuhan pelayanan diluar kapasitas sehingga menyebabkan pelanggan menunggu mendapatkan pelayanan (Supriyadi et al., 2018). Antrian merupakan salah satu bentuk contoh pelayanan yang kurang baik, sebab hal tersebut mengakibatkan konsumen harus menunggu untuk dilayani (Hasian \& Putra, 2010).

Antrian dapat terjadi pada beberapa tempat, terutama pada fasilitas umum yang banyak dibutuhkan oleh masyarakat umum, salah satunya yaitu pada Stasiun Pengisian Bahan Bakar Umum (SPBU). Jumlah fasilitas yang terbatas menyebabkan pada situasi tertentu pelanggan harus mengantri untuk memenuhi kebutuhan bahan bakar sepeda motor (Manalu \& Palandeng, 2019). Identifikasi pihak-pihak terkait sangat diperlukan untuk menganalisa antrian yang terjadi itu akan menguntungkan ataupun merugikan. Analisis sistem tersebut digunakan untuk mengurangi atau meminimalkan jumlah antrian yang terjadi sehingga pelanggan merasa nyaman dengan pelayaan yang diperoleh (Kusumaningtyas et al., 2018).

Antrian di SPBU merupakan salah satu hal yang cukup sering terjadi, seperti contohnya yaitu pada SPBU Pertamina 14.243.435 di Lhokseumawe. Pada jam sibuk sering terjadi antrian kendaraan yang panjang untuk mengisi bahan bakar sepeda motor. Antrian bisa sampai 5-10 sepeda motor yang membuat konsumen kurang sabar dan memilih mencari tempat lain untuk mengisi bahan bakar (Amri \& Muhammad, 2013). Hal ini berdampak pada kekurangnyamanan konsumen dalam memperoleh pelayan yang diharapkan. Tidak hanya di daerah tersebut, antrian pada SPBU juga terjadi di daerah Batam, seperti pada SPBU 14.294.739 yang berlokasi di Jl. Raja H. Fisabilillah yang menjadi objek dalam penelitian ini. Kondisi antrian di SPBU tersebut secara garis besar dapat dilihat melalui tabel di bawah ini, yang dimana hanya dikhususkan pada kendaraan sepeda motor (roda dua) dengan jenis pengisian bahan bakar premium dan pertalite. Hal ini dikarenakan pada stasiun pengisian bahan bakar roda dua mengalami antrian yang Panjang hingga 3 meter. Dan hal itu menyebabkan gangguan bagi kendaraan lain seperti, mobil dan truk saat akan mengisi bahan bakar.

Tabel 1. Data Tingkat Kedatangan

\begin{tabular}{ccc}
\hline Periode Waktu & $\begin{array}{c}\text { Rata-Rata } \\
\text { Tingkat } \\
\text { Kedatangan } \\
\text { Sepeda } \\
\text { Motor } \\
\text { (Premium) }\end{array}$ & $\begin{array}{c}\text { Rata-Rata } \\
\text { Tingkat } \\
\text { Kedatangan } \\
\text { Sepeda } \\
\text { Motor } \\
\text { (Pertalite) }\end{array}$ \\
\hline $07.00-08.00$ & 50 & 40 \\
$08.00-09.00$ & 40 & 35 \\
$09.00-10.00$ & 55 & 48 \\
$10.00-11.00$ & 35 & 30 \\
$11.00-12.00$ & 45 & 50 \\
\hline
\end{tabular}

Berdasarkan pada data tabel 1 yang telah diperoleh melalui studi pendahuluan sebelumnya, maka alasan dipilihnya SPBU tersebut sebagai objek penelitian disebabkan karena tingginya tingkat rata-rata kedatangan sepeda motor di SPBU Jl. Raja H. Fisabilillah, khususnya pada pengisian bahan bakar premium dan pertalite untuk sepeda motor. Hal tersebut mengakibatkan sering terjadinya antrian untuk mendapatkan pelayanan. Selain menyebabkan gangguan bagi kendaraan lain, hal ini juga menyebabkan tingkat kepuasaan konsumen turun baik konsumen yang menggunakan roda dua maupun roda empat maupun lebih.

Penelitian ini bertujuan untuk menganalisis kondisi sistem antrian pengisian bahan bakar pada SPBU Jl. Raja H. Fisabilillah yang dikhususkan pada kendaraan roda dua dengan jenis bahan bakar premium dan pertalite melalui simulasi dengan menggunakan software Arena versi 16 (student version). Tujuan dari studi simulasi pada sistem antrian di SPBU Jl. Raja H. Fisabilillah adalah untuk meningkatkan pelayanan pengisian bahan bakar pada kendaraan roda dua dengan jenis bahan bakar premium dan pertalite yang didapat dari nilai utilitas yang menunjukkan penurunan nilai dari 1 yang menandakan adanya kesibukan pada server ke nilai kurang dari 1, yaitu utilisasi masing-masing server berjalan dengan baik pada masing-masing server sehingga dapat berdampak pada minimnya tingkat antrian dalam sistem.

\section{METODE PENELITIAN}

Penelitian ini menggunakan penelitian kuantitatif. Metode penelitian kuantitatif yaitu metode penelitian yang berlandaskan pada filsafat positivisme, digunakan untuk meneliti pada populasi atau sampel tertentu, pengumpulan data menggunakan instrumen penelitian, analisis data bersifat kuantitatif/statistik, dengan tujuan untuk 
menguji hipotesis yang telah ditetapkan (Sekaran \& Bougie, 2016). Jenis data yang digunakan pada penelitian ini adalah data kuantitatif, yaitu data yang merupakan perhitungan statistik yang digunakan untuk menghitung jumlah jalur fasilitas yang optimal dan kinerja waktu pelayanan fasilitas pada tingkat optimal saat pengisian ulang bahan bakar umum di SPBU. Sumber data yang digunakan dalam penelitian ini adalah data primer berupa jumlah kedatangan pelanggan atau orang yang akan mengantri untuk melakukan pengisian ulang bahan bakar umum di SPBU.

Populasi adalah wilayah generalisasi yang terdiri atas subyek atau obyek yang mempunyai kualitas atau karakteristik tertentu yang ditetapkan oleh peneliti untuk dipelajari dan kemudian ditarik kesimpulannya (Sugiyono, 2008). Populasi dari penelitian ini adalah fasilitas pengisian bahan bakar di SPBU JI. Raja H. Fisabilillah. Sampel yang diambil pada penelitian ini yaitu pelanggan yang datang dan mengantri untuk mengisi bahan bakar pada di SPBU JI. Raja H. Fisabilillah. Penelitian ini menggunakan teknik nonprobability sampling. Nonprobability sampling adalah pengambilan sampel yang berubah-ubah dan subyektif. Unsur populasi yang terpilih menjadi sampel bisa disebabkan karena kebetulan atau, setiap populasi tidak mempunyai kesempatan untuk dimasukkan sebagai sampel. Setiap anggota populasi tidak mempunyai kesempatan untuk dimasukkan sebagai sampel (Cooper \& Schindler, 2011). Pengambilan sampel dilakukan pada tanggal 29 April dan untuk jamnya menggunakan sesi pagi hari yaitu pukul 16:40 17:40. Sampel tersebut mewakili pelanggan yang melakukan antrian untuk pengisian bahan bakar di SPBU JI. Raja H. Fisabilillah.

Dalam proses pelayanan guna melayani pelanggan, SPBU menggunakan Model Multiple Channel Query System artinya terdapat lebih dari satu jalur fasilitas dan hanya ada satu tahapan pelayanan yang harus dilalui oleh pelanggan untuk menyelesaikan pelayanan (Handoko \& Astuti, 2017; Rachman, 2013). Waktu yang dibutuhkan oleh pelanggan bersifat acak (random), karena jumlah kebutuhan setiap pelanggan berbeda-beda. SPBU menerapkan pelayanan first-come, first-served (FCFS), dimana pelanggan yang datang pertama akan dilayani terlebih dahulu (Strang, 2012). Untuk mengoptimalkan proses pelayanan dapat digunakan rumus antrian untuk Model Multiple Channel Query System sebagai berikut.

a. Probabilitas terdapat 0 orang dalam sistem (tidak adanya pelanggan dalam sistem).

$$
P o=\frac{1}{\left[\sum_{N=0}^{M-1} \frac{1}{n !}\left(\frac{\lambda}{\mu}\right)^{n}\right]+\frac{1}{M !}\left(\frac{\lambda}{\mu}\right)^{M} \frac{M \mu}{M \lambda-\mu}}
$$

b. Jumlah pelanggan rata-rata dalam sistem (Ls) merupakan jumlah rata-rata pelanggan yang menunggu untuk dilayani oleh fasilitas pelayanan dan termasuk pelanggan yang sedang dilayani.

$$
L s=\frac{\lambda \mu(\lambda / \mu)^{M}}{(M-1) !(M \mu-\lambda)^{2}} P o+\frac{\lambda}{\mu}
$$

c. Waktu rata-rata antrian dalam sistem (Ws) merupakan rata-rata keseluruhan waktu dari pelanggan yang menunggu pelayanan dan waktu rata-rata fasilitas dalam menyelesaikan pelayanan.

$$
W s=\frac{L s}{\lambda}
$$

d. Jumlah orang atau unit rata-rata yang menunggu dalam antrian (Lq) merupakan banyaknya (jumlah) permintaan pelayanan yang datang menunggu dari pelanggan untuk dilayani.

$$
L q=L s-\frac{\lambda}{\mu}
$$

e. Waktu rata-rata yang dihabiskan oleh seorang pelanggan atau unit untuk menunggu dalam antrian (Wq) merupakan lamanya waktu yang diperlukan oleh pelanggan yang datang dan antri untuk mendapat pelayanan.

$$
W q=\frac{L q}{\lambda}
$$

\section{HASIL DAN PEMBAHASAN}

Pada penelitian ini, pengamatan dilakukan pada SPBU JI. Raja H. Fisabilillah yang dikhususkan pada kendaraan roda dua dengan jenis bahan bakar premium dan pertalite. Pengisian kedua bahan bakar tersebut menerapkan model antrian single channel single phase (Gambar 1). Aktivitas pengisian bahan bakar baik pada premium maupun pertalite dimulai dari kendaraan roda dua yang datang dan masuk ke dalam sistem untuk kemudian menunggu hingga pelayanan pengisian bahan bakar dilakukan oleh operator. Setelah itu, pelanggan akan melakukan pembayaran dan selanjutnya akan keluar dari sistem.

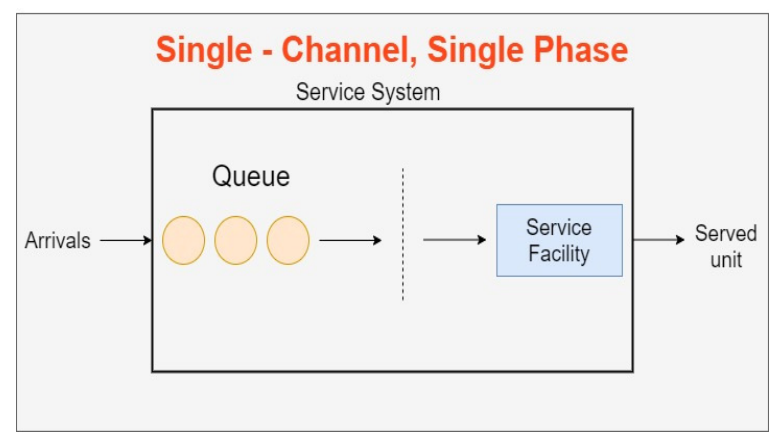

Gambar 1. Ilustrasi Sistem Antrian

Data yang digunakan merupakan data hasil pengamatan yang dilakukan pada tanggal 29 
Maret 2020 hingga tanggal 08 April 2020, dengan durasi waktu pengamatan selama 1 sampai 2 jam, dimulai dari pukul 16.40 WIB dan berakhir pada 18.40 WIB. Pemilihan waktu tersebut dikarenakan disaat jam tersebut merupakan waktu terjadinya antrian dan merupakan jam sibuk bagi server dan operator dalam pelayanan pengisian bahan bakar.
Pengamatan dilakukan terhadap waktu kedatangan kendaraan roda dua, waktu awal pelayanan dan waktu selesai. Data tersebut selanjutnya direkapitulasi ke dalam Ms. Excel untuk kemudian dicari selisih waktu antar kedatangan, waktu proses dan waktu antrian (Tabel 2 dan Tabel 3).

Tabel 2. Data Hasil Observasi Antrian Premium

\begin{tabular}{|c|c|c|c|c|c|c|c|c|}
\hline $\begin{array}{c}\text { Kendaraan } \\
\mathrm{Ke}-\end{array}$ & $\begin{array}{c}\text { Waktu } \\
\text { Kedatangan }\end{array}$ & $\begin{array}{l}\text { Waktu Awal } \\
\text { Pelayanan }\end{array}$ & $\begin{array}{l}\text { Waktu } \\
\text { Selesai }\end{array}$ & $\begin{array}{l}\text { Waktu Antar } \\
\text { Kedatangan }\end{array}$ & $\begin{array}{l}\text { Waktu Antar } \\
\text { Kedatangan } \\
\text { (Detik) }\end{array}$ & $\begin{array}{l}\text { Waktu } \\
\text { Proses }\end{array}$ & $\begin{array}{l}\text { Waktu } \\
\text { Proses } \\
\text { (Detik) }\end{array}$ & $\begin{array}{l}\text { Waktu } \\
\text { Antrian }\end{array}$ \\
\hline 1 & $16: 40: 01$ & $16: 40: 26$ & $16: 40: 43$ & $0: 01: 00$ & 60 & $0: 00: 17$ & 17 & $0: 00: 25$ \\
\hline 2 & $16: 40: 04$ & $16: 40: 54$ & $16: 41: 09$ & $0: 00: 03$ & 3 & $0: 00: 15$ & 15 & $0: 00: 50$ \\
\hline 3 & $16: 41: 25$ & $16: 41: 32$ & $16: 42: 04$ & $0: 01: 21$ & 81 & 0:00:32 & 32 & $0: 00: 07$ \\
\hline 4 & $16: 45: 43$ & $16: 45: 47$ & $16: 46: 08$ & $0: 04: 18$ & 258 & $0: 00: 21$ & 21 & $0: 00: 04$ \\
\hline 5 & $16: 47: 14$ & $16: 47: 16$ & $16: 47: 43$ & 0:01:31 & 91 & 0:00:27 & 27 & 0:00:02 \\
\hline 6 & $16: 47: 58$ & $16: 48: 29$ & $16: 48: 44$ & $0: 00: 44$ & 44 & 0:00:15 & 15 & $0: 00: 31$ \\
\hline 7 & $16: 49: 36$ & $16: 49: 42$ & $16: 49: 58$ & 0:01:38 & 98 & 0:00:16 & 16 & 0:00:06 \\
\hline 8 & $16: 52: 30$ & $16: 52: 40$ & $16: 53: 10$ & $0: 02: 54$ & 174 & 0:00:30 & 30 & $0: 00: 10$ \\
\hline 9 & $16: 54: 01$ & $16: 54: 05$ & $16: 54: 25$ & $0: 01: 31$ & 91 & $0: 00: 20$ & 20 & $0: 00: 04$ \\
\hline 10 & $16: 57: 16$ & $16: 57: 20$ & $16: 57: 55$ & 0:03:15 & 195 & 0:00:35 & 35 & 0:00:04 \\
\hline 11 & $16: 57: 42$ & $16: 59: 40$ & $17: 00: 07$ & 0:00:26 & 26 & $0: 00: 27$ & 27 & $0: 01: 58$ \\
\hline 12 & $16: 58: 16$ & $17: 00: 22$ & $17: 00: 49$ & $0: 00: 34$ & 34 & 0:00:27 & 27 & 0:02:06 \\
\hline 13 & $16: 58: 17$ & $17: 00: 56$ & $17: 01: 18$ & 0:00:01 & 1 & 0:00:22 & 22 & $0: 02: 39$ \\
\hline 14 & $17: 01: 07$ & 17:01:24 & $17: 01: 50$ & $0: 02: 50$ & 170 & 0:00:26 & 26 & $0: 00: 17$ \\
\hline 15 & $17: 03: 12$ & $17: 03: 19$ & $17: 03: 52$ & 0:02:05 & 125 & 0:00:33 & 33 & 0:00:07 \\
\hline 16 & $17: 03: 51$ & $17: 04: 39$ & $17: 05: 18$ & $0: 00: 39$ & 39 & $0: 00: 39$ & 39 & $0: 00: 48$ \\
\hline 17 & $17: 04: 21$ & $17: 05: 30$ & $17: 05: 53$ & 0:00:30 & 30 & 0:00:23 & 23 & 0:01:09 \\
\hline 18 & $17: 05: 50$ & $17: 06: 01$ & $17: 06: 23$ & 0:01:29 & 89 & 0:00:22 & 22 & $0: 00: 11$ \\
\hline 19 & $17: 07: 55$ & 17:08:03 & 17:08:20 & 0:02:05 & 125 & 0:00:17 & 17 & 0:00:08 \\
\hline 20 & $17: 08: 10$ & $17: 08: 41$ & $17: 08: 56$ & $0: 00: 15$ & 15 & 0:00:15 & 15 & $0: 00: 31$ \\
\hline 21 & $17: 08: 45$ & $17: 09: 33$ & $17: 09: 57$ & 0:00:35 & 35 & 0:00:24 & 24 & $0: 00: 48$ \\
\hline 22 & $17: 09: 33$ & $17: 10: 15$ & $17: 10: 28$ & $0: 00: 48$ & 48 & 0:00:13 & 13 & $0: 00: 42$ \\
\hline 23 & $17: 10: 06$ & $17: 10: 52$ & $17: 11: 10$ & $0: 00: 33$ & 33 & $0: 00: 18$ & 18 & $0: 00: 46$ \\
\hline 24 & $17: 11: 00$ & $17: 11: 19$ & $17: 12: 03$ & $0: 00: 54$ & 54 & $0: 00: 44$ & 44 & $0: 00: 19$ \\
\hline 25 & $17: 12: 10$ & $17: 12: 14$ & $17: 12: 35$ & $0: 01: 10$ & 70 & 0:00:21 & 21 & $0: 00: 04$ \\
\hline 26 & $17: 13: 23$ & $17: 13: 29$ & $17: 14: 15$ & $0: 01: 13$ & 73 & 0:00:46 & 46 & 0:00:06 \\
\hline 27 & $17: 14: 24$ & $17: 14: 46$ & $17: 15: 14$ & 0:01:01 & 61 & 0:00:28 & 28 & 0:00:22 \\
\hline 28 & $17: 14: 24$ & $17: 15: 17$ & $17: 15: 41$ & $0: 00: 00$ & 0 & $0: 00: 24$ & 24 & $0: 00: 53$ \\
\hline 29 & $17: 15: 36$ & $17: 16: 01$ & $17: 16: 26$ & $0: 01: 12$ & 72 & 0:00:25 & 25 & $0: 00: 25$ \\
\hline 30 & $17: 16: 51$ & $17: 17: 15$ & $17: 17: 43$ & $0: 01: 15$ & 75 & $0: 00: 28$ & 28 & $0: 00: 24$ \\
\hline 31 & $17: 17: 27$ & $17: 17: 59$ & $17: 18: 15$ & 0:00:36 & 36 & 0:00:16 & 16 & $0: 00: 32$ \\
\hline 32 & $17: 18: 36$ & $17: 19: 18$ & $17: 19: 45$ & 0:01:09 & 69 & $0: 00: 27$ & 27 & $0: 00: 42$ \\
\hline 33 & $17: 19: 27$ & $17: 20: 22$ & $17: 20: 52$ & $0: 00: 51$ & 51 & 0:00:30 & 30 & $0: 00: 55$ \\
\hline 34 & $17: 19: 50$ & $17: 21: 22$ & $17: 21: 39$ & $0: 00: 23$ & 23 & $0: 00: 17$ & 17 & $0: 01: 32$ \\
\hline 35 & $17: 21: 22$ & $17: 22: 18$ & $17: 22: 31$ & 0:01:32 & 92 & 0:00:13 & 13 & $0: 00: 56$ \\
\hline 36 & $17: 22: 24$ & $17: 23: 17$ & $17: 23: 31$ & 0:01:02 & 62 & 0:00:14 & 14 & $0: 00: 53$ \\
\hline 37 & $17: 23: 21$ & $17: 24: 12$ & $17: 24: 25$ & $0: 00: 57$ & 57 & $0: 00: 13$ & 13 & $0: 00: 51$ \\
\hline 38 & $17: 24: 32$ & $17: 24: 39$ & $17: 24: 56$ & 0:01:11 & 71 & 0:00:17 & 17 & 0:00:07 \\
\hline 39 & $17: 25: 19$ & $17: 25: 59$ & $17: 26: 17$ & $0: 00: 47$ & 47 & 0:00:18 & 18 & $0: 00: 40$ \\
\hline 40 & $17: 25: 44$ & $17: 26: 48$ & $17: 27: 04$ & $0: 00: 25$ & 25 & $0: 00: 16$ & 16 & $0: 01: 04$ \\
\hline 41 & $17: 25: 58$ & $17: 27: 07$ & $17: 27: 28$ & 0:00:14 & 14 & 0:00:21 & 21 & 0:01:09 \\
\hline 42 & $17: 26: 28$ & $17: 27: 47$ & $17: 28: 04$ & 0:00:30 & 30 & $0: 00: 17$ & 17 & $0: 01: 19$ \\
\hline 43 & $17: 27: 12$ & $17: 28: 18$ & $17: 28: 38$ & $0: 00: 44$ & 44 & 0:00:20 & 20 & 0:01:06 \\
\hline 44 & $17: 28: 02$ & $17: 30: 06$ & $17: 30: 27$ & $0: 00: 50$ & 50 & $0: 00: 21$ & 21 & $0: 02: 04$ \\
\hline 45 & $17: 29: 12$ & $17: 31: 40$ & $17: 32: 09$ & $0: 01: 10$ & 70 & 0:00:29 & 29 & $0: 02: 28$ \\
\hline 46 & $17: 30: 09$ & $17: 32: 59$ & $17: 33: 33$ & $0: 00: 57$ & 57 & $0: 00: 34$ & 34 & $0: 02: 50$ \\
\hline 47 & $17: 32: 58$ & $17: 34: 16$ & $17: 34: 30$ & $0: 02: 49$ & 169 & $0: 00: 14$ & 14 & $0: 01: 18$ \\
\hline 48 & $17: 34: 10$ & $17: 34: 34$ & $17: 34: 46$ & 0:01:12 & 72 & 0:00:12 & 12 & $0: 00: 24$ \\
\hline 49 & $17: 34: 44$ & $17: 35: 54$ & $17: 36: 10$ & $0: 00: 34$ & 34 & 0:00:16 & 16 & $0: 01: 10$ \\
\hline 50 & $17: 35: 39$ & $17: 36: 20$ & $17: 36: 42$ & 0:00:55 & 55 & 0:00:22 & 22 & $0: 00: 41$ \\
\hline 51 & $17: 36: 20$ & $17: 37: 18$ & $17: 37: 47$ & $0: 00: 41$ & 41 & 0:00:29 & 29 & $0: 00: 58$ \\
\hline 52 & $17: 37: 24$ & $17: 38: 05$ & $17: 38: 27$ & 0:01:04 & 64 & 0:00:22 & 22 & $0: 00: 41$ \\
\hline 53 & $17: 37: 53$ & $17: 39: 06$ & $17: 39: 26$ & 0:00:29 & 29 & 0:00:20 & 20 & $0: 01: 13$ \\
\hline 54 & $17: 38: 40$ & $17: 39: 32$ & $17: 39: 54$ & $0: 00: 47$ & 47 & $0: 00: 22$ & 22 & $0: 00: 52$ \\
\hline 55 & $17: 39: 49$ & $17: 40: 55$ & $17: 41: 12$ & 0:01:09 & 69 & $0: 00: 17$ & 17 & 0:01:06 \\
\hline
\end{tabular}


Tabel 3. Data Hasil Observasi Antrian Pertalite

\begin{tabular}{|c|c|c|c|c|c|c|c|c|}
\hline $\begin{array}{c}\text { Kendaraan } \\
\text { Ke- }\end{array}$ & $\begin{array}{c}\text { Waktu } \\
\text { Kedatangan }\end{array}$ & $\begin{array}{c}\text { Waktu Awal } \\
\text { Pelayanan }\end{array}$ & $\begin{array}{l}\text { Waktu } \\
\text { Selesai }\end{array}$ & $\begin{array}{l}\text { Waktu Antar } \\
\text { Kedatangan }\end{array}$ & $\begin{array}{l}\text { Waktu Antar } \\
\text { Kedatangan } \\
\text { (Detik) }\end{array}$ & $\begin{array}{l}\text { Waktu } \\
\text { Proses }\end{array}$ & $\begin{array}{l}\text { Waktu } \\
\text { Proses } \\
\text { (Detik) }\end{array}$ & $\begin{array}{l}\text { Waktu } \\
\text { Antrian }\end{array}$ \\
\hline 1 & $16: 43: 23$ & $16: 43: 28$ & $16: 43: 49$ & 0:03:23 & 203 & 0:00:21 & 21 & $0: 00: 05$ \\
\hline 2 & $16: 43: 39$ & $16: 44: 02$ & $16: 44: 34$ & $0: 00: 16$ & 16 & $0: 00: 32$ & 32 & $0: 00: 23$ \\
\hline 3 & $16: 47: 16$ & $16: 47: 53$ & $16: 48: 24$ & 0:03:37 & 217 & 0:00:31 & 31 & $0: 00: 37$ \\
\hline 4 & $16: 48: 00$ & $16: 48: 54$ & $16: 49: 14$ & 0:00:44 & 44 & 0:00:20 & 20 & $0: 00: 54$ \\
\hline 5 & $16: 51: 25$ & $16: 51: 36$ & $16: 51: 57$ & 0:03:25 & 205 & $0: 00: 21$ & 21 & $0: 00: 11$ \\
\hline 6 & $16: 57: 18$ & $16: 57: 28$ & $16: 57: 43$ & 0:05:53 & 353 & $0: 00: 15$ & 15 & $0: 00: 10$ \\
\hline 7 & $16: 57: 22$ & $16: 57: 55$ & $16: 58: 10$ & 0:00:04 & 4 & $0: 00: 15$ & 15 & $0: 00: 33$ \\
\hline 8 & $16: 58: 06$ & $16: 58: 13$ & $16: 58: 30$ & $0: 00: 44$ & 44 & $0: 00: 17$ & 17 & 0:00:07 \\
\hline 9 & $16: 58: 08$ & $16: 58: 36$ & $16: 59: 02$ & 0:00:02 & 2 & $0: 00: 26$ & 26 & $0: 00: 28$ \\
\hline 10 & $16: 58: 09$ & $16: 59: 11$ & $16: 59: 43$ & 0:00:01 & 1 & $0: 00: 32$ & 32 & $0: 01: 02$ \\
\hline 11 & $16: 58: 19$ & $16: 59: 51$ & $17: 00: 06$ & 0:00:10 & 10 & 0:00:15 & 15 & 0:01:32 \\
\hline 12 & $16: 58: 38$ & $17: 00: 10$ & $17: 00: 33$ & $0: 00: 19$ & 19 & $0: 00: 23$ & 23 & $0: 01: 32$ \\
\hline 13 & 17:02:02 & 17:02:04 & $17: 02: 25$ & 0:03:24 & 204 & 0:00:21 & 21 & 0:00:02 \\
\hline 14 & $17: 03: 42$ & 17:04:01 & $17: 04: 23$ & $0: 01: 40$ & 100 & 0:00:22 & 22 & $0: 00: 19$ \\
\hline 15 & $17: 04: 42$ & $17: 04: 45$ & $17: 05: 20$ & 0:01:00 & 60 & $0: 00: 35$ & 35 & 0:00:03 \\
\hline 16 & $17: 05: 14$ & $17: 05: 45$ & $17: 06: 21$ & 0:00:32 & 32 & $0: 00: 36$ & 36 & $0: 00: 31$ \\
\hline 17 & $17: 05: 52$ & $17: 06: 26$ & $17: 06: 44$ & $0: 00: 38$ & 38 & $0: 00: 18$ & 18 & $0: 00: 34$ \\
\hline 18 & 17:05:59 & $17: 06: 55$ & 17:07:20 & 0:00:07 & 7 & $0: 00: 25$ & 25 & 0:00:56 \\
\hline 19 & $17: 08: 33$ & 17:09:01 & $17: 09: 21$ & $0: 02: 34$ & 154 & $0: 00: 20$ & 20 & $0: 00: 28$ \\
\hline 20 & 17:09:22 & $17: 09: 24$ & $17: 09: 45$ & 0:00:49 & 49 & $0: 00: 21$ & 21 & $0: 00: 02$ \\
\hline 21 & $17: 10: 27$ & $17: 10: 34$ & $17: 10: 56$ & 0:01:06 & 66 & 0:00:22 & 22 & 0:00:07 \\
\hline 22 & $17: 11: 01$ & $17: 11: 20$ & $17: 11: 43$ & $0: 00: 34$ & 34 & $0: 00: 23$ & 23 & $0: 00: 19$ \\
\hline 23 & $17: 11: 36$ & 17:12:03 & $17: 12: 34$ & 0:00:34 & 34 & 0:00:31 & 31 & $0: 00: 27$ \\
\hline 24 & $17: 12: 40$ & $17: 12: 44$ & $17: 13: 05$ & $0: 01: 04$ & 64 & $0: 00: 21$ & 21 & 0:00:04 \\
\hline 25 & 17:13:28 & $17: 14: 27$ & $17: 14: 43$ & 0:00:48 & 48 & 0:00:16 & 16 & 0:00:59 \\
\hline 26 & $17: 14: 42$ & $17: 14: 53$ & $17: 15: 10$ & $0: 01: 14$ & 74 & $0: 00: 17$ & 17 & $0: 00: 11$ \\
\hline 27 & $17: 15: 16$ & $17: 15: 26$ & $17: 16: 17$ & 0:00:34 & 34 & $0: 00: 51$ & 51 & $0: 00: 10$ \\
\hline 28 & $17: 15: 51$ & $17: 16: 45$ & $17: 17: 00$ & 0:00:35 & 35 & $0: 00: 15$ & 15 & 0:00:54 \\
\hline 29 & $17: 18: 34$ & $17: 18: 41$ & $17: 19: 01$ & $0: 02: 43$ & 163 & 0:00:20 & 20 & 0:00:07 \\
\hline 30 & $17: 18: 41$ & 17:19:52 & $17: 20: 05$ & 0:00:07 & 7 & $0: 00: 13$ & 13 & $0: 01: 11$ \\
\hline 31 & $17: 19: 41$ & $17: 21: 02$ & $17: 21: 15$ & 0:01:00 & 60 & $0: 00: 13$ & 13 & 0:01:21 \\
\hline 32 & $17: 21: 02$ & $17: 21: 45$ & $17: 22: 04$ & 0:01:21 & 81 & 0:00:19 & 19 & $0: 00: 43$ \\
\hline 33 & $17: 21: 45$ & $17: 22: 38$ & $17: 23: 10$ & 0:00:43 & 43 & 0:00:32 & 32 & 0:00:53 \\
\hline 34 & $17: 22: 26$ & $17: 23: 41$ & $17: 24: 01$ & $0: 00: 41$ & 41 & 0:00:20 & 20 & $0: 01: 15$ \\
\hline 35 & $17: 23: 40$ & $17: 24: 03$ & $17: 24: 10$ & 0:01:14 & 74 & 0:00:07 & 7 & 0:00:23 \\
\hline 36 & $17: 23: 46$ & $17: 24: 13$ & $17: 24: 45$ & 0:00:06 & 6 & 0:00:32 & 32 & $0: 00: 27$ \\
\hline 37 & $17: 24: 16$ & $17: 24: 55$ & $17: 25: 23$ & 0:00:30 & 30 & $0: 00: 28$ & 28 & $0: 00: 39$ \\
\hline 38 & $17: 24: 55$ & $17: 25: 34$ & $17: 25: 54$ & 0:00:39 & 39 & 0:00:20 & 20 & 0:00:39 \\
\hline 39 & $17: 25: 21$ & $17: 26: 21$ & $17: 26: 32$ & $0: 00: 26$ & 26 & $0: 00: 11$ & 11 & $0: 01: 00$ \\
\hline 40 & $17: 26: 38$ & $17: 26: 40$ & $17: 27: 19$ & 0:01:17 & 77 & 0:00:39 & 39 & 0:00:02 \\
\hline 41 & $17: 26: 40$ & $17: 27: 40$ & $17: 28: 00$ & 0:00:02 & 2 & $0: 00: 20$ & 20 & 0:01:00 \\
\hline 42 & $17: 27: 46$ & $17: 28: 50$ & $17: 29: 10$ & 0:01:06 & 66 & 0:00:20 & 20 & 0:01:04 \\
\hline 43 & $17: 28: 25$ & $17: 29: 15$ & $17: 29: 31$ & 0:00:39 & 39 & $0: 00: 16$ & 16 & 0:00:50 \\
\hline 44 & $17: 28: 53$ & $17: 29: 58$ & $17: 30: 12$ & $0: 00: 28$ & 28 & $0: 00: 14$ & 14 & 0:01:05 \\
\hline 45 & $17: 29: 00$ & $17: 30: 17$ & $17: 30: 35$ & 0:00:07 & 7 & 0:00:18 & 18 & $0: 01: 17$ \\
\hline 46 & $17: 29: 03$ & $17: 30: 38$ & $17: 30: 59$ & 0:00:03 & 3 & $0: 00: 21$ & 21 & $0: 01: 35$ \\
\hline 47 & $17: 29: 08$ & $17: 31: 14$ & $17: 31: 27$ & 0:00:05 & 5 & $0: 00: 13$ & 13 & 0:02:06 \\
\hline 48 & $17: 31: 06$ & $17: 31: 45$ & $17: 31: 56$ & 0:01:58 & 118 & $0: 00: 11$ & 11 & 0:00:39 \\
\hline 49 & $17: 31: 32$ & $17: 32: 02$ & $17: 32: 38$ & $0: 00: 25$ & 25 & $0: 00: 36$ & 36 & $0: 00: 30$ \\
\hline 50 & $17: 34: 24$ & $17: 35: 03$ & $17: 35: 37$ & 0:02:52 & 172 & 0:00:34 & 34 & 0:00:39 \\
\hline 51 & $17: 35: 58$ & $17: 36: 53$ & $17: 37: 13$ & $0: 01: 34$ & 94 & 0:00:20 & 20 & $0: 00: 55$ \\
\hline 52 & $17: 37: 30$ & $17: 38: 42$ & $17: 38: 55$ & 0:01:32 & 92 & $0: 00: 13$ & 13 & $0: 01: 12$ \\
\hline 53 & $17: 38: 49$ & $17: 40: 11$ & $17: 40: 23$ & 0:01:19 & 79 & $0: 00: 12$ & 12 & 0:01:22 \\
\hline 54 & $17: 39: 09$ & $17: 40: 27$ & $17: 40: 45$ & $0: 00: 20$ & 20 & $0: 00: 18$ & 18 & $0: 01: 18$ \\
\hline
\end{tabular}

Data-data observasi yang telah di rekapitulasi kemudian diolah dengan menggunakan Input Analyzer untuk menentukan jenis distribusi data. Berdasarkan pengolahan data dengan menggunakan Input Analyzer, maka diperoleh hasil bahwa jenis distribusi waktu antar kedatangan konsumen premium memiliki distribusi Weibull dengan nilai expression $-0.001+$ WEIB $(70.2,1.24)$ dan nilai square error sebesar
0.036620 . Jenis distribusi waktu proses konsumen premium memiliki distribusi Weibull dengan nilai expression 11.5 + WEIB $(12.4,1.48)$ dan nilai square error sebesar 0.014019 (Gambar 2). Berdasarkan pengolahan data dengan menggunakan Input Analyzer dapat diperoleh hasil bahwa jenis distribusi waktu antar kedatangan konsumen pertalite memiliki distribusi Weibull dengan nilai expression $0.999+$ WEIB 
$(59.9,0.846)$ dan nilai square error sebesar 0.010303 . Jenis distribusi waktu proses konsumen pertalite memiliki distribusi Gamma dengan nilai expression $6.5+\operatorname{GAMM}(5.13,3)$ dan nilai square error sebesar 0.028558 (Gambar 3).

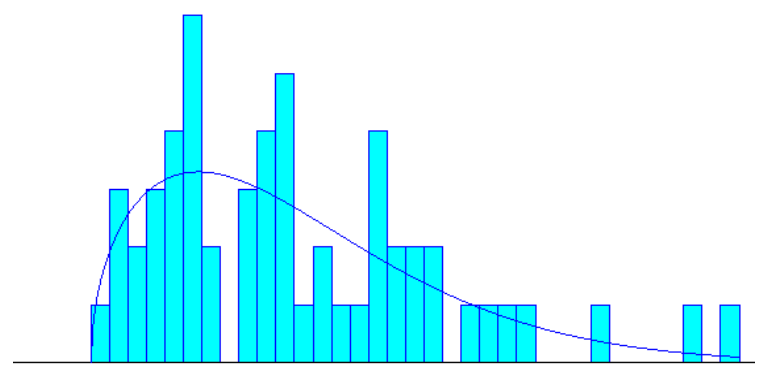

Gambar 2. Data Waktu Proses Konsumen Premium

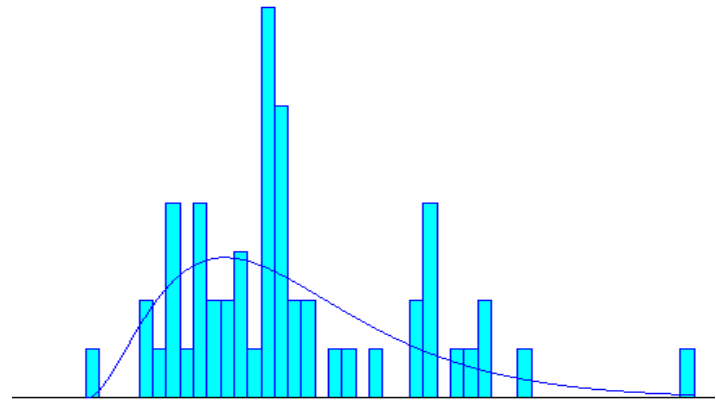

Gambar 3. Data Waktu Proses Konsumen Pertalite

Setelah menganalisa jenis distribusi data, maka selanjutnya dilakukan pembuatan model simulasi dengan menggunakan software Arena. Terdapat beberapa event yang terjadi dalam proses antrian pada pembuatan model simulasi (Gambar 4), diantaranya yaitu:

a. Proses Kedatangan Kendaraan, yang digambarkan dengan modul "Create".

b. Proses Pelayanan, yang digambarkan dengan modul "Process".

c. Proses Meninggalkan Server, yang digambarkan dengan modul "Dispose".

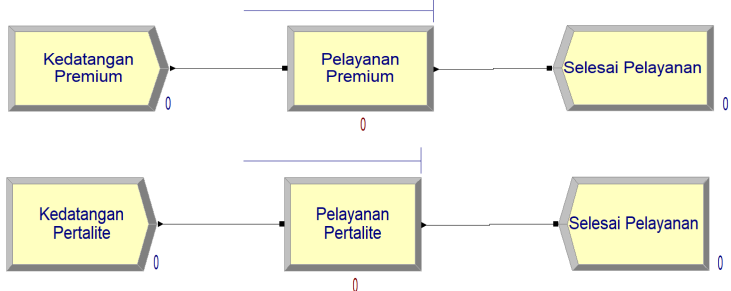

Gambar 4. Model Logika Arena

Selanjutnya, dilakukan pengisian data pada setiap modul-modul Arena dan kemudian dilakukan pula proses verifikasi untuk membuktikan apakah model yang dibuat telah benar (Gambar 5).

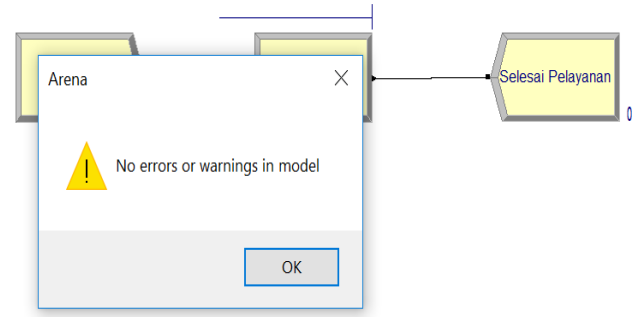

Gambar 5. Verifikasi Model pada Premium dan Pertalite

Setelah simulasi dari model tersebut selesai dijalankan, maka akan diperoleh report dari sistem antrian tersebut. Berdasarkan report tersebut, diperoleh hasil bahwa rata-rata waktu tunggu untuk stasiun premium adalah 0.0052 dengan nilai maksimumnya yang juga bernilai sama. Dapat diketahui pula bahwa dalam satu jam pengamatan, jumlah kendaraan yang masuk ialah sekitar 48 kendaraan dengan rata-rata waktu proses pelayanan setiap kendaraan yaitu sekitar 24 detik, dimana waktu maksimum pelayanannya sekitar 47 detik.

Sedangkan pada stasiun pertalite, rata-rata waktu tunggu 0.0048 dengan nilai maksimumnya yang juga bernilai sama. Dapat diketahui pula bahwa dalam satu jam pengamatan, jumlah kendaraan yang masuk ialah sekitar 45 kendaraan dengan rata-rata waktu proses pelayanan setiap kendaraan yaitu sekitar 22 detik, dimana waktu maksimum pelayanannya sekitar 44 detik. Serta, berdasarkan hasil simulasi diperoleh juga nilai dari waiting time bernilai 0 , baik pada stasiun premium maupun pertalite. Hal tersebut menunjukkan bahwa model yang disimulasikan tidak menghasilkan antrian. Selain Entity dan juga Queue, tingkat utilitas server juga dapat diketahui melalui hasil report pada bagian Resource. Melalui report tersebut, dapat diketahui bahwa nilai instantaneous utilization dan number busy baik pada premium maupun pertalite bernilai 1. Hal tersebut menunjukkan bahwa utilitas server sangat tinggi, dimana server dalam keadaan sibuk serta bekerja terlalu banyak dan maksimal.

Percobaan simulasi disini bertujuan untuk mengetahui pengaruh dari beberapa faktor terhadap performansi sistem yang dikaji (Srivathsan \& Viswanathan, 2017; Wu \& McGinnis, 2012). Adapun ukuran performansi sistem yang dikaji adalah nilai utilitas dari server. Nilai utilitas menunjukkan tingkat kesibukkan dari server. Faktor yang diduga mempengaruhi nilai utilitas dari server adalah jumlah server pengisian dan jumlah operator di dalam server.

Dalam hal ini, diberikan alternatif perbaikan terhadap kinerja sistem yang bertujuan untuk mengatasi permasalahan yang terjadi pada 
sistem tersebut yakni nilai utilitas yang bernilai 1 . Usulan perbaikan yang diberikan adalah dengan penambahan jumlah server dan operator (Gambar 6, Gambar 7, dan Gambar 8).

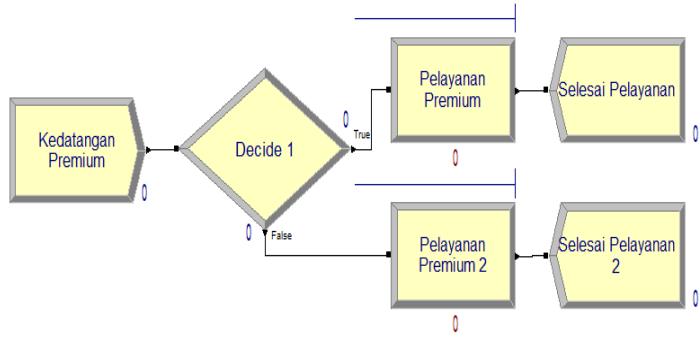

Gambar 6. Usulan Perbaikan Premium

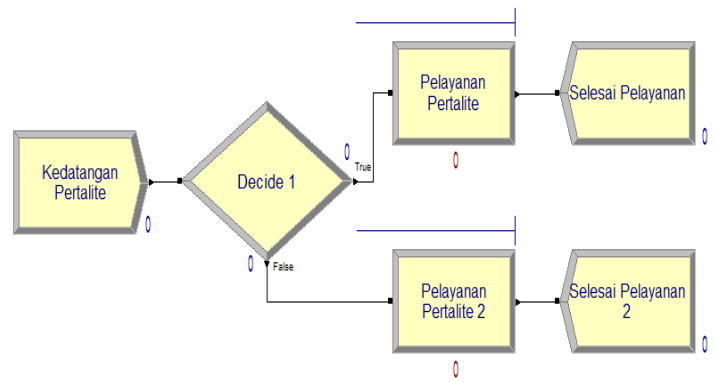

Gambar 7. Usulan Perbaikan Pertalite

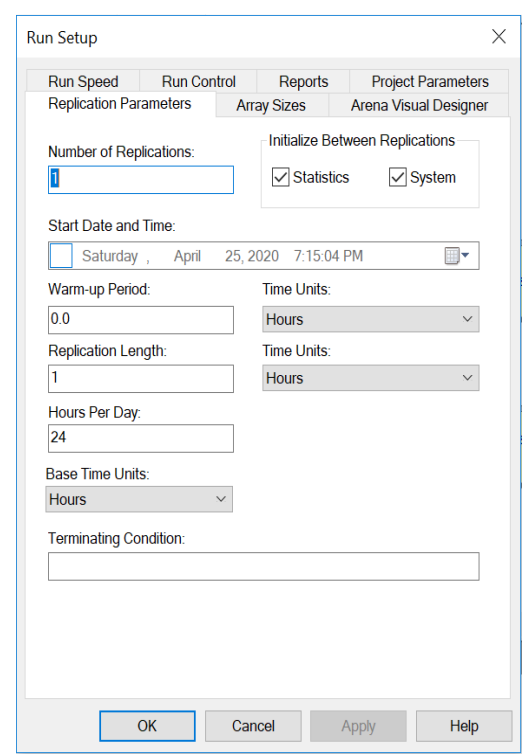

Gambar 8. Run Setup pada Usulan Perbaikan Premium dan Pertalite

Setelah simulasi dari model tersebut selesai dijalankan, maka akan diperoleh report dari usulan perbaikan sistem antrian tersebut. Dengan menambahkan jumlah server dan jumlah operator, sehingga terdapat 2 server pada premium dan 2 server pada pertalite yang dimana masing-masing server memiliki 2 operator, maka didapatkan output utilitas yang bernilai lebih kecil dari kondisi sistem yang ada sebelumnya.

\section{Resource}

Usage

\begin{tabular}{lcccr} 
Instantaneous Utilization & Average & Half Width & $\begin{array}{r}\text { Minimum } \\
\text { Value }\end{array}$ & $\begin{array}{r}\text { Maximum } \\
\text { Value }\end{array}$ \\
\hline Operator 1 & 0.1330 & (Insufficient) & 0.00 & 1.0000 \\
Operator 2 & 0.1330 & (Insufficient) & 0.00 & 1.0000 \\
Operator 3 & 0.1584 & (Insufficient) & 0.00 & 1.0000 \\
Operator 4 & 0.1584 & (Insufficient) & 0.00 & 1.0000
\end{tabular}

Gambar 9. Report Resource pada Usulan Perbaikan Premium

\begin{tabular}{lrrrr}
\hline Resource & & & & \\
\hline Usage & & & & \\
Instantaneous Utilization & & & & \\
& Average & Half Width & $\begin{array}{r}\text { Minimum } \\
\text { Value }\end{array}$ & $\begin{array}{r}\text { Maximum } \\
\text { Value }\end{array}$ \\
\hline Operator 1 & 0.1199 & (Insufficient) & 0.00 & 1.0000 \\
Operator 2 & 0.1199 & (Insufficient) & 0.00 & 1.0000 \\
Operator 3 & 0.1761 & (Insufficient) & 0.00 & 1.0000 \\
Operator 4 & 0.1761 & (Insufficient) & 0.00 & 1.0000
\end{tabular}

Gambar 10. Report Resource pada Usulan Perbaikan Pertalite

Nilai utilitas server pada lini premium dan pertalite mengalami penurunan yang cukup signifikan sehingga berada di bawah angka 1 (Gambar 9 dan Gambar 10). Hal tersebut menunjukkan bahwa dengan menambahkan jumlah server dan operator dapat menurunkan nilai utilitas server, sehingga server tidak lagi berada dalam keadaan bekerja terlalu banyak seperti kondisi sistem sebelumnya. Selain itu, dapat diketahui pula jumlah pelanggan yang dapat dilayani pada masing-masing server selama 2 jam dalam sistem usulan perbaikan tersebut. Pada lini premium, server pertama dapat melayani sebanyak 22 pelanggan dan server kedua dapat melayani sebanyak 24 pelanggan, sehingga total yang dapat dilayani pada lini premium ialah sebanyak 46 pelanggan selama 2 jam. Sedangkan pada lini pertalite, server pertama dapat melayani sebanyak 22 pelanggan dan server kedua dapat melayani sebanyak 26 pelanggan, sehingga total yang dapat dilayani pada lini pertalite ialah sebanyak 48 pelanggan.

\section{KESIMPULAN}

Berdasarkan hasil simulasi tersebut, dapat disimpulkan bahwa pada SPBU 14.294.739 yang berlokasi di Jl. Raja H. Fisabilillah, Kota Batam pada pengisian bahan bakar premium dan pertalite khusus kendaraan roda dua memiliki nilai utilitas pada masing-masing server sebesar 1 , dimana hal ini mengakibatkan server berada dalam keadaan yang sibuk dan bekerja terlalu banyak. Oleh karena itu, maka dilakukanlah perancangan alternatif perbaikan sistem dengan 
melakukan penambahan jumlah server dari 1 menjadi 2 server pada masing-masing jalur pengisian bahan bakar premium dan pertalite serta menambahkan jumlah operator pada masing-masing server, dari 1 operator menjadi 2 operator. Dengan usulan tersebut, didapatkan nilai utilitas server premium dan pertalite mengalami penurunan yang cukup signifikan, sehingga server tidak lagi terlalu sibuk dan bekerja terlalu banyak. Penelitian lanjutan yang dapat dilakukan adalah penelitian untuk keseluruhan sistem SPBU, dimana pengamatan tidak hanya dilakukan pada kendaraan roda dua saja, melainkan juga pada kendaraan roda empat sehingga simulasi yang dibuat dapat lebih menyerupai sistem nyata.

\section{DAFTAR PUSTAKA}

Amri, \& Muhammad. (2013). Analisis Sistem Antrian pada Stasiun Pengisian Bahan Bakar Umum (SPBU) dengan Menggunakan Simulasi Arena. Malikussaleh Industrial Engineering Journal, 2(2), 16-23. https://jurnal.unimal.ac.id/miej/article/view/7 4

Cooper, D. R., \& Schindler, P. S. (2011). Business Research Methods. McGraw-Hill Higher Education; McGraw-Hill Higher Education.

Dewi, R. S. (2016). Analisis Kepuasan Konsumen pada Pedagang Kaki Lima di Kawasan Simpang Lima Semarang. Jurnal Administrasi Bisnis, 5(1), 13-23. https://ejournal.undip.ac.id/index.php/janis/a rticle/view/12719

Handoko, H., \& Astuti, S. W. (2017). Queue Analysis at Yogyakarta Tugu Station. Jurnal Perkeretaapian Indonesia, 1(2), 105-115. https://doi.org/10.37367/jpi.v1i2.37

Hasian, D. P., \& Putra, A. K. (2010). Simulasi Pelayanan Pengisian Bahan Bakar di SPBU Gunung Pangilun. Jurnal Optimasi Sistem Industri, 9(1), 31-36. https://doi.org/10.25077/josi.v9.n1.p3136.2010

Kusumaningtyas, Fikri, M. I., \& Liquiddanu, E. (2018). Simulasi Antrian Pengisian Bahan Bakar di SPBU Pucangsawit. Seminar Dan Konferensi Nasional IDEC, 1-11. https://idec.ft.uns.ac.id/wpcontent/uploads/2018/05/ID012.pdf

Manalu, C., \& Palandeng, I. (2019). Analisis Sistem Antrian Sepeda Motor pada Stasiun Pengisian Bahan Bakar Umum (SPBU) 74.951.02 Malalayang. Jurnal EMBA, 7(1), 551-560.

https://ejournal.unsrat.ac.id/index.php/emba /article/view/22444
Rachman, T. (2013). Simulasi Model Antrian Optimal Loket Pembayaran Parkir. J. Inovisi, 12(2), 72-85. https://ejurnal.esaunggul.ac.id/index.php/ino visi/article/view/1919

Sekaran, U., \& Bougie, R. (2016). Research methods for business: $A$ skill building approach. John Wiley \& Sons.

Srivathsan, S., \& Viswanathan, S. (2017). A queueing-based optimization model for planning inventory of repaired components in a service center. Computers \& Industrial Engineering, 106, 373-385. https://doi.org/10.1016/j.cie.2017.01.020

Strang, K. D. (2012). Importance of verifying queue model assumptions before planning with simulation software. European Journal of Operational Research, 218(2), 493-504. https://doi.org/10.1016/j.ejor.2011.10.054

Sugiyono. (2008). Metode Penelitian Pendidikan: Pendekatan Kuantitatif, Kualitatif dan R\&D. Alfabeta.

Supriyadi, S., Alfarisi, S., Karno, R., \& Cahyadi, D. (2018). Queue Design of Bank Teller Service in Banten, Indonesia. Proceedings of the The 1st International Conference on Computer Science and Engineering Technology Universitas Muria Kudus, 165171. https://doi.org/10.4108/eai.24-102018.2280631

Wihdaniah, S., Pono, M., \& Munizu, M. (2018). Analisis Kinerja Sistem Antrian dalam Mengoptimalkan Pelayanan Pasien Rawat Jalan di RSUD Haji Makassar. Jurnal Bisnis, Manajemen Dan Informatika, 14(3), 228238.

https://journal.unhas.ac.id/index.php/jbmi/art icle/view/3333

Wu, K., \& McGinnis, L. (2012). Performance evaluation for general queueing networks in manufacturing systems: Characterizing the trade-off between queue time and utilization. European Journal of Operational Research, 221(2), 328-339. https://doi.org/10.1016/j.ejor.2012.03.019 